\title{
Effect of High-Pressure Treatment and a Bacteriocin-Producing Lactic Culture on the Proteolysis, Texture, and Taste of Hispánico Cheese
}

\author{
M. Ávila, S. Garde, P. Gaya, M. Medina, and M. Nuñez ${ }^{1}$ \\ Departamento de Tecnología de Alimentos Instituto Nacional de Investigación y Tecnología Agraria y Alimentaria (INIA) Madrid, 28040 Spain
}

\begin{abstract}
The effects of high-pressure treatment, by itself or in combination with a bacteriocin-producing culture added to milk, on the proteolysis, texture, and taste of Hispánico cheese were investigated. Two vats of cheese were manufactured from a mixture of cow and ewe milk. Milk in one vat was inoculated with $0.5 \%$ Lactococcus lactis ssp. lactis INIA 415, a nisin Z and lacticin 481 producer; $0.5 \%$ L. lactis ssp. lactis INIA $415-2$, a bacteriocin-nonproducing mutant; and $2 \%$ of a commercial Streptococcus thermophilus culture. Milk in the other vat was inoculated with $1 \%$ L. lactis ssp. lactis INIA $415-2$ and $2 \%$ S. thermophilus culture. After ripening for $15 \mathrm{~d}$ at $12^{\circ} \mathrm{C}$, half of the cheeses from each vat were treated at $400 \mathrm{MPa}$ for $5 \mathrm{~min}$ at $10^{\circ} \mathrm{C}$. Ripening of highpressure-treated and untreated cheeses continued at $12^{\circ} \mathrm{C}$ until d 50. High-pressure treatment of cheese made from milk without the bacteriocin producer accelerated casein degradation and increased the free AA content, but it did not significantly influence the taste quality or taste intensity of the cheese. Addition of the bacteriocin producer to milk lowered the ratio of hydrophobic peptides to hydrophilic peptides, increased the free AA content, and enhanced the taste intensity. The combination of milk inoculation with the bacteriocin producer and high-pressure treatment of the cheese resulted in higher levels of both hydrophobic and hydrophilic peptides but had no significant effect on the free AA content, taste quality, or taste intensity.
\end{abstract}

Key words: high pressure, bacteriocin, cheese, proteolysis

\section{INTRODUCTION}

Ripening of hard cheese varieties is a long and costly process. Therefore, a shortened cheese-ripening period would lead to a considerable reduction in manufacturing costs. During ripening, milk proteins, fat, lactose, citrate, and lactate are broken down or transformed

Received November 18, 2005.

Accepted March 24, 2006.

${ }^{1}$ Corresponding author: nunez@inia.es into metabolites that include a high number of flavor compounds. These biochemical changes are carried out by milk enzymes, rennet, starter cultures, and secondary microbiota.

Lactic acid bacteria (LAB) contribute to cheese ripening through the production of metabolites that influence cheese texture and sensory characteristics. They are also an important source of enzymes such as proteinases, peptidases, AA catabolic enzymes, and esterases, which transform milk constituents retained in the curd into low molecular weight compounds (Fox et al., 1996). Lysis of starter cells will favor the access of intracellular enzymes of LAB to their substrates and presumably will accelerate cheese ripening.

To enhance the lysis of LAB during cheese manufacture and early ripening, bacteriocin-producing $(\mathbf{B P})$ adjunct cultures may be added to milk. Strains of BP-LAB used by different groups have been mostly lactococci, although enterococci were also investigated for this purpose. Lactococcus lactis ssp. lactis DPC3286, a producer of lactococcins $\mathrm{A}, \mathrm{B}$, and $\mathrm{M}$, increased the concentration of free AA (FAA) and reduced bitterness scores when used as an adjunct culture in Cheddar cheese manufacture (Morgan et al., 1997). Enterococcus faecalis INIA 4, a producer of AS-48 enterocin, accelerated cell lysis, cheese proteolysis, and flavor development when added to milk as an adjunct culture in the manufacture of Hispánico cheese (Garde et al., 1997). Nonprotein and amino nitrogen levels were increased in a semihard cheese when a lacticin 3147-producing L. lactis strain was used as a starter culture (Martínez-Cuesta et al., 2001). Addition of L. lactis ssp. lactis INIA 415, a producer of nisin $\mathrm{Z}$ and lacticin 481, increased the release of aminopeptidase activity, rate of proteolysis, and amount of FAA in Hispánico cheese made from milk inoculated with $L$. lactis ssp. lactis INIA 415-2, a spontaneous bacteriocin-nonproducing (BNP) mutant, and a Streptococcus thermophilus culture (Ávila et al., 2005).

Another method used to accelerate the lysis of starter cells and subsequent cheese ripening is high-pressure (HP) treatment of the cheese. The permeability of the lactococcal cell membrane is increased by HP treatment (Malone et al., 2002), favoring the release of intracellu- 
lar material such as peptidases to the cheese matrix (Trujillo et al., 2000). On the other hand, HP treatment may induce conformational changes in the casein structure, making the protein more susceptible to the action of proteases (Kunugi, 1993). A faster $\alpha_{\mathrm{s} 1}$-casein degradation and an increase in $\mathrm{pH} 4.6$-soluble nitrogen and FAA were reported for Cheddar cheese treated at 50 $\mathrm{MPa}$ for $72 \mathrm{~h}$ at $25^{\circ} \mathrm{C}$ (O'Reilly et al., 2000). Treatment of Garrotxa goat milk cheese at $400 \mathrm{MPa}$ for $5 \mathrm{~min}$ at $14^{\circ} \mathrm{C}$ increased the FAA (Saldo et al., 2002). A higher FAA content was reported for ewe milk cheese treated at $300 \mathrm{MPa}$ for $10 \mathrm{~min}$ at $12^{\circ} \mathrm{C}$ than for untreated control cheese and for cheeses treated at 400 or $500 \mathrm{MPa}$ (Juan et al., 2004).

Hispánico cheese is a semihard Spanish variety made from a mixture of cow and ewe milks. It stands as a representative of the varieties made from a mixture of milks from more than one species, which account for more than $50 \%$ of the cheese produced in Spain. In the present work, HP treatment of Hispánico cheese after ripening for $15 \mathrm{~d}$, by itself or in combination with a $\mathrm{BP}$ adjunct culture added to the milk, was investigated with the aim of accelerating the ripening process. The effects on the proteolysis, texture, and taste of Hispánico during cheese ripening are reported herein.

\section{MATERIALS AND METHODS}

\section{Lactic Cultures}

Lactococcus lactis ssp. lactis INIA 415, a producer of nisin $\mathrm{Z}$ and lacticin 481, from the INIA (Instituto Nacional de Investigación y Tecnología Agraria y Alimentaria) culture collection, was used as the BP culture. Lactococcus lactis ssp. lactis INIA 415-2 is a spontaneous nisin- and lacticin 481-resistant BNP mutant, with acid production and proteolytic activities similar to those of the parental strain. Both strains were maintained at $-80^{\circ} \mathrm{C}$ in de Man, Rogosa and Sharpe broth (MRS broth; Biolife, Milano, Italy) and subcultured twice in reconstituted skim milk at $30^{\circ} \mathrm{C}$ before use as mesophilic starters in cheese manufacture. Commercial lactic culture TA052 (Rhodia Iberia, Madrid, Spain) consists of $S$. thermophilus strains of high aminopeptidase activity. It was subcultured twice in reconstituted skim milk at $37^{\circ} \mathrm{C}$ before use in cheese manufacture.

\section{Cheese Manufacture}

Hispánico cheese was manufactured in duplicate experiments on different days from a mixture of pasteurized cow (80\%) and ewe (20\%) milk. Each experiment was conducted in two 100-L vats. Concentrations of lactic cultures were chosen following laboratory-scale cheese-making trials. Lactic cultures for vat 1 (BNP cheeses) were $1 \%$ BNP culture and $2 \%$ S. thermophilus culture. Lactic cultures for vat 2 (BP cheeses) were $0.5 \%$ BNP culture, $0.5 \%$ BP culture, and $2 \%$ S. thermophilus culture. Rennet (6 mL of Maxiren, 1:15,000 strength; Gist Brocades, Delft, The Netherlands) was added to the milk 60 min after lactic culture inoculation. After the milk had coagulated at $33^{\circ} \mathrm{C}$ for $40 \mathrm{~min}$, the curds were cut into 6 - to $8-\mathrm{mm}$ cubes and scalded at $37^{\circ} \mathrm{C}$ for $15 \mathrm{~min}$. The whey was drained off and the curds were distributed into cylindrical moulds. Six cheeses, approximately $2 \mathrm{~kg}$ in weight, were obtained from each vat. The cheeses were pressed overnight at $20^{\circ} \mathrm{C}$ and $1.5 \mathrm{~kg} / \mathrm{cm}^{2}$ pressure, salted for $24 \mathrm{~h}$ at $12^{\circ} \mathrm{C}$ in $160 \mathrm{~g}$ of $\mathrm{NaCl} / \mathrm{L}$ of brine, and ripened at $12^{\circ} \mathrm{C}$ and $85 \%$ relative humidity for $50 \mathrm{~d}$. Cheeses were coated on d 7 with 2 layers of pimaricine-containing polyvinyl acetate.

\section{HP Treatment}

After $15 \mathrm{~d}$ of ripening, 3 cheeses from each vat (BNPHP and BP-HP cheeses) were vacuum-packaged in CN300 bags (Cryovac Grace S.A., Barcelona, Spain) and pressurized at $400 \mathrm{MPa}$ for $5 \mathrm{~min}$ at an initial temperature of $10^{\circ} \mathrm{C}$, by means of a 100 -L capacity discontinuous isostatic press at NC Hyperbaric (Burgos, Spain). Come-up time to reach $400 \mathrm{MPa}$ was $5.9 \mathrm{~min}$, and depressurization time was $1.8 \mathrm{~min}$. The temperature of the water used as a pressure-transmitting fluid did not exceed $14^{\circ} \mathrm{C}$ during the process. After treatment, the BNP-HP and BP-HP cheeses were unpacked and followed ripening until d 50. The other 3 cheeses from each vat, which were not pressurized (NHP cheeses), were not vacuum-packaged.

\section{Microbiological Analysis}

Viable counts of LAB were determined in duplicate on plate count agar (Liofilchem, Roseto, Italy) with $0.1 \%$ skim milk (Biolife) added, using a DS Plus Spiral plater (Interscience, Saint-Nom-La-Bretèche, France). Previous trials had shown that lactococci were the only colony formers on plates incubated aerobically for $24 \mathrm{~h}$ at $30^{\circ} \mathrm{C}$, and that thermophilic streptococci were the only colony formers on plates incubated aerobically for $24 \mathrm{~h}$ at $40^{\circ} \mathrm{C}$. Bacteriocin-producing lactococci were determined on the surface of double-layer APT agar plates (Biolife), with the lower layer inoculated with $0.1 \%$ of a $16-\mathrm{h}$ culture of Lactobacillus buchneri St2A as the indicator microorganism; colonies forming a zone of growth inhibition in the lower layer were considered to be L. lactis ssp. lactis INIA 415.

\section{Bacteriocin Activity}

For the determination of bacteriocin activity, cheese samples held at $-40^{\circ} \mathrm{C}$ were thawed and 5-g amounts 
were homogenized in a Stomacher 400 (Seward Laboratory, London, England) with $10 \mathrm{~mL}$ of sterile $0.02 \mathrm{~N}$ $\mathrm{HCl}$ at $50^{\circ} \mathrm{C}$. Homogenates were centrifuged $(12,000 \times$ $\mathrm{g}, 20 \mathrm{~min}, 4^{\circ} \mathrm{C}$ ) and the $\mathrm{pH}$ of fat-free supernatants was adjusted to $\mathrm{pH} 6$ with $1 \mathrm{~N} \mathrm{NaOH}$. A $30-\mu \mathrm{L}$ volume of each supernatant was placed in triplicate into 5-mmdiameter wells made in plates of APT agar inoculated with $0.1 \%$ of a 16 -h culture of $L b$. buchneri St2A as the indicator microorganism. After incubation at $30^{\circ} \mathrm{C}$ for $48 \mathrm{~h}$, the diameter of the zone of growth inhibition was measured and bacteriocin activity was expressed in millimeters.

\section{Aminopeptidase Activity}

Aminopeptidase activity released into the cheese was measured in duplicate samples on an extract obtained by homogenizing $10 \mathrm{~g}$ of cheese with $20 \mathrm{~mL}$ of $10 \mathrm{mM}$ sodium phosphate buffer, $\mathrm{pH} 7$, at $20^{\circ} \mathrm{C}$ for $3 \mathrm{~min}$ in a Stomacher 400 instrument, followed by centrifuging $\left(10,000 \times g, 15 \mathrm{~min}, 4^{\circ} \mathrm{C}\right)$ and filtering through Whatman No. 2 filter paper. Lysine $p$-nitroanilide and Leu$p$-nitroanilide were used as substrates. One activity unit corresponds to the activity of enzyme (s) producing $1 \mathrm{nmol}$ of $p$-nitroaniline per minute per gram of cheese.

\section{Chemical Determinations}

Cheese $\mathrm{pH}$ was measured in duplicate by means of a Crison pH meter (model GPL 22; Crison Instruments, Barcelona, Spain) using a Crison penetration electrode (model 52-3,2). Dry matter was determined after drying to constant weight in a vacuum oven at $100^{\circ} \mathrm{C}$.

Residual caseins were determined by capillary electrophoresis using a Beckman P/ACE System 2100 (Beckman Instruments España, Madrid, Spain) controlled by a System Gold Software data system, as previously described (Garde et al., 2002). Residual caseins in cheese were expressed as percentages of the total amount of the respective casein initially present in milk, taking into account the weights of the milk and cheese sampled (Garde et al., 2002).

Cheese overall proteolysis was determined on duplicate samples by the $o$-phthaldialdehyde (OPA) test, based on the reaction of released $\alpha$-amino groups with this compound and with $\beta$-mercaptoethanol to form an adduct that absorbs strongly at $340 \mathrm{~nm}$ (Church et al., 1983).

Hydrophilic and hydrophobic peptides in the watersoluble fraction of cheese were determined on duplicate samples by reversed-phase HPLC using a Beckman System Gold chromatograph (Beckman Instruments España) equipped with a diode array detector module 168 , with detection wavelength at $214 \mathrm{~nm}$, as previously described (Lau et al., 1991; Gómez et al., 1997). Peaks with retention times from 8.5 to 14.6 min were considered to correspond to hydrophilic peptides, and those with retention times from 14.6 to $20.5 \mathrm{~min}$ to hydrophobic peptides. Results were expressed as units of chromatogram area per milligram of cheese DM.

Free AA were extracted from duplicate samples of cheese (Krause et al., 1995) and individual AA were determined by reversed-phase HPLC using a Beckman System Gold chromatograph, after derivatization with 6-aminoquinolyl- $N$-hydroxysuccinimidyl carbamate. Results are expressed as milligrams per kilogram of cheese DM.

\section{Textural Determinations}

Fracturability (breaking force, expressed in newtons), hardness (work after 75\% compression, expressed in joules), and elasticity (apparent elastic module, expressed in newtons per square millimeter) were calculated from the compression curves (6 determinations per cheese) obtained using an Instron Compression Tester 4301 (Instron, High Wycombe, Bucks, UK) as previously described (Gaya et al., 1990).

\section{Sensory Evaluation}

Eleven trained panelists evaluated the cheeses at 15, 25 , and $50 \mathrm{~d}$ of ripening for quality (overall acceptance) and intensity (overall intensity) of taste on a 0 - to 10 point scale, using a horizontal line anchored in the middle and at both ends. Taste was defined as the sensation felt by the taste buds. Cheese samples were held for $3 \mathrm{~h}$ at 20 to $22^{\circ} \mathrm{C}$ prior to sensorial evaluation. After removing the rind, cheeses were cut in representative triangular slices (15 to $20 \mathrm{~g}$ ). Slices of 4 cheeses per session (one HP cheese and one NHP cheese from each of the 2 vats manufactured on the same day) coded with random 3-digit numbers, were randomly presented to panelists. Bread and water were used as rinsing agents between cheeses. Panelists were asked to assign a score on a 0- to 6-point scale, using a horizontal line anchored in the middle and at both ends, to the intensity of the following taste attributes: "sour," "bitter," "sweet," "salty," and "umami."

\section{Statistical Analysis}

Statistical treatment of data was performed by means of SPSS for Windows 8.0 (SPSS Inc., Chicago, IL). Multifactor ANOVA were carried out, considering composition of the mesophilic culture, HP treatment, and cheese age as main effects. Additionally, variable means for the 4 types of cheese (BNP-NHP, BNP-HP, 
HIGH PRESSURE, BACTERIOCINS, AND CHEESE PROTEOLYSIS

Table 1. Lactic acid bacteria (LAB) in Hispánico cheese manufactured without (BNP) or with (BP) a bacteriocin-producing adjunct culture, high-pressure treated (HP) on d 15 or untreated (NHP) ${ }^{1}$

\begin{tabular}{lcllll}
\hline LAB & Age, d & BNP-NHP & BNP-HP & BP-NHP & BP-HP \\
\hline Mesophilic & 1 & $8.16 \pm 0.07^{\mathrm{a}}$ & - & $9.57 \pm 0.02^{\mathrm{b}}$ & - \\
& 7 & $8.06 \pm 0.05^{\mathrm{a}}$ & - & $9.38 \pm 0.01^{\mathrm{b}}$ & - \\
& 15 & $8.04 \pm 0.01^{\mathrm{b}}$ & $7.96 \pm 0.01^{\mathrm{a}}$ & $9.62 \pm 0.01^{\mathrm{d}}$ & $8.50 \pm 0.03^{\mathrm{c}}$ \\
& 25 & $7.82 \pm 0.05^{\mathrm{a}}$ & $8.05 \pm 0.01^{\mathrm{b}}$ & $9.64 \pm 0.04^{\mathrm{c}}$ & $8.07 \pm 0.12^{\mathrm{b}}$ \\
Thermophilic & 50 & $8.10 \pm 0.01^{\mathrm{c}}$ & $7.65 \pm 0.07^{\mathrm{b}}$ & $9.68 \pm 0.01^{\mathrm{d}}$ & $6.37 \pm 0.02^{\mathrm{a}}$ \\
& 1 & $9.27 \pm 0.02^{\mathrm{b}}$ & - & $8.09 \pm 0.03^{\mathrm{a}}$ & - \\
& 7 & $9.32 \pm 0.06^{\mathrm{b}}$ & - & $8.53 \pm 0.02^{\mathrm{a}}$ & - \\
& 15 & $9.45 \pm 0.01^{\mathrm{d}}$ & $8.54 \pm 0.05^{\mathrm{c}}$ & $8.45 \pm 0.06^{\mathrm{b}}$ & $8.09 \pm 0.04^{\mathrm{a}}$ \\
& 25 & $9.40 \pm 0.05^{\mathrm{d}}$ & $8.71 \pm 0.02^{\mathrm{c}}$ & $8.07 \pm 0.09^{\mathrm{b}}$ & $6.92 \pm 0.24^{\mathrm{a}}$ \\
& 50 & $9.44 \pm 0.03^{\mathrm{d}}$ & $8.09 \pm 0.05^{\mathrm{b}}$ & $8.25 \pm 0.09^{\mathrm{c}}$ & $7.15 \pm 0.09^{\mathrm{a}}$ \\
\hline
\end{tabular}

${ }^{\mathrm{a}-\mathrm{d}}$ Means in the same row with different superscripts differ $(P<0.05)$.

${ }^{1}$ Mean $\pm \mathrm{SE}(\mathrm{n}=4)$ of duplicate determinations in 2 cheese-making experiments of LAB, expressed as log colony-forming units per gram of cheese.

BP-NHP, BP-HP) at 15, 25, and $50 \mathrm{~d}$ of ripening were compared using Tukey's test. Principal components analysis using Varimax rotation with Kaiser normalization was carried out on highly correlated $(|\mathrm{r}|>0.6)$ proteolysis variables, taste attributes, and $\mathrm{pH}$ using the same program.

\section{RESULTS AND DISCUSSION}

\section{Lactic Acid Bacteria}

Counts of mesophilic LAB corresponded to L. lactis ssp. lactis INIA 415 and its BNP mutant in BP cheeses, and exclusively to the BNP mutant in BNP cheeses. Mesophilic LAB counts were approximately $1.5 \mathrm{log}$ units higher in BP-NHP cheese than in BNP-NHP cheese throughout ripening (Table 1), probably because growth of mesophilic LAB was favored in the former cheese by bacteriocins inhibiting the thermophilic LAB. Treatment of BNP cheese at $400 \mathrm{MPa}$ for $5 \mathrm{~min}$ at $10^{\circ} \mathrm{C}$ lowered the mesophilic LAB counts on $\mathrm{d} 15$ by only $0.1 \log$ units (Table 1), equivalent to a $17 \%$ reduction. Counts of $4 \mathrm{~L}$. lactis strains were reduced by 2 to $5 \mathrm{log}$ units in 1-d-old Cheddar cheese treated at $400 \mathrm{MPa}$ for $20 \mathrm{~min}$ at $25^{\circ} \mathrm{C}$ (O'Reilly et al., 2002). Also, treatment of 15-d-old ewe milk cheese at $400 \mathrm{MPa}$ for $10 \mathrm{~min}$ at $12^{\circ} \mathrm{C}$ lowered L. lactis counts by 5 log units (Juan et al., 2004), and treatment of 30-d-old Cheddar cheese at $400 \mathrm{MPa}$ for $5 \mathrm{~min}$ at $25^{\circ} \mathrm{C}$ lowered L. lactis counts by $4.7 \mathrm{log}$ units (Wick et al., 2004). The low reduction of mesophilic LAB counts in BNP cheeses recorded in our experiment may be explained by the fact that barotolerance of microorganisms within a certain species is usually strain dependent, and also by our HP conditions, which were milder in time or in temperature than those used in the works mentioned above. However, HP treatment of BP cheese reduced mesophilic LAB counts by $1.1 \log$ units on d 15 (Table 1), equivalent to a $92 \%$ reduction. The presence of bacteriocin in $\mathrm{BP}$ cheese seemed to increase the lethality of the HP treatment. A clear synergy has been observed for the combined effect of HP treatment and milk inoculation with BP$\mathrm{LAB}$ on the elimination of different pathogens in cheese (Arqués et al., 2005; Rodríguez et al., 2005).

Thermophilic LAB counts were approximately $1 \mathrm{log}$ unit lower in BP-NHP cheese than in BNP-NHP cheese throughout ripening (Table 1) because of the inhibition by bacteriocins, in agreement with previous results (Ávila et al., 2005). High-pressure treatment lowered thermophilic LAB counts in BNP cheese by 0.9 log units on d 15 (Table 1), equivalent to an $88 \%$ reduction. Treatment of low-fat yogurt at $400 \mathrm{MPa}$ for $15 \mathrm{~min}$ at $20^{\circ} \mathrm{C}$ reduced $S$. thermophilus counts by $1.8 \log$ units (Ancos et al., 2000), whereas treatment of fermented milk at $400 \mathrm{MPa}$ for $30 \mathrm{~min}$ lowered counts of $7 \mathrm{~S}$. thermophilus strains by 0.5 to $5.0 \mathrm{log}$ units (Reps et al., 2001). Highpressure treatment reduced thermophilic LAB counts in BP cheese by only $0.4 \log$ units on d 15 (Table 1 ), equivalent to a $56 \%$ reduction, lower than that found in BNP cheese. A plausible explanation for the higher baroresistance of $S$. thermophilus in BP cheese is the induction by bacteriocins of an unspecific mechanism of resistance in this bacterial species (Garde et al., 2004).

Bacteriocin-producing LAB accounted for $25 \%$ of mesophilic LAB in BP-NHP cheese on d 1 and for $35 \%$ on d 15 (Table 2). High-pressure treatment lowered BPLAB counts by 1.2 log units on d 15 (Table 2), equivalent to a $94 \%$ reduction, similar to that found for mesophilic LAB counts.

\section{Bacteriocin Activity}

Bacteriocin activity increased in BP-NHP cheese until d 15 and remained stable during the rest of the ripening period (Table 2). In BP-HP cheese, bacteriocin activity was considerably reduced by HP treatment on 
Table 2. Bacteriocin-producing lactic acid bacteria (BP-LAB) and bacteriocin activity in Hispánico cheese manufactured without (BNP) or with (BP) a bacteriocin-producing adjunct culture, high-pressure treated (HP) on d 15 or untreated (NHP) ${ }^{1}$

\begin{tabular}{lcllll}
\hline Activity & Age, d & BNP-NHP & BNP-HP & BP-NHP & BP-HP \\
\hline BP-LAB & 1 & ND & - & $8.97 \pm 0.02$ & - \\
& 7 & ND & - & $8.93 \pm 0.02$ & - \\
& 15 & ND & ND & $9.17 \pm 0.04^{\mathrm{b}}$ & $7.96 \pm 0.08^{\mathrm{a}}$ \\
& 25 & ND & ND & $9.34 \pm 0.03^{\mathrm{b}}$ & $7.73 \pm 0.05^{\mathrm{a}}$ \\
& 50 & ND & ND & $9.22 \pm 0.09^{\mathrm{b}}$ & $5.91 \pm 0.03^{\mathrm{a}}$ \\
Bacteriocin & 1 & ND & - & $8.8 \pm 0.8$ & - \\
& 7 & ND & - & $10.5 \pm 0.5$ & - \\
& 15 & ND & ND & $12.5 \pm 0.8^{\mathrm{b}}$ & $8.8 \pm 1.0^{\mathrm{a}}$ \\
& 25 & ND & ND & $12.4 \pm 0.5^{\mathrm{b}}$ & $7.3 \pm 1.2^{\mathrm{a}}$ \\
& 50 & ND & ND & $12.9 \pm 1.0^{\mathrm{b}}$ & $6.8 \pm 0.7^{\mathrm{a}}$ \\
\hline
\end{tabular}

${ }^{\mathrm{a}, \mathrm{b}}$ Means in the same row with different superscripts differ $(P<0.05)$.

${ }^{1}$ Mean $\pm \mathrm{SE}(\mathrm{n}=4)$ of duplicate determinations in 2 cheese-making experiments of BP-LAB, expressed as log colony-forming units per gram of cheese, and bacteriocin activity, expressed as diameter ( $\mathrm{mm}$ ) of the zone of growth inhibition. ND = not detected.

d 15, and afterward it remained at lower levels than in BP-NHP cheese (Table 2). High-pressure treatment of cheese might have induced conformational changes in the structure of bacteriocins, lowering their biological activity. On the other hand, the reduction of BP-LAB counts by HP treatment negatively affected bacteriocin production in BP-HP cheese from d 15 onward. A decrease of bacteriocin activity in cheeses made with nisin Z- or lacticin 481-producing L. lactis strains was recorded after HP treatment (Arqués et al., 2005).

\section{Cheese $\mathrm{pH}$ and $\mathrm{DM}$}

Cheese $\mathrm{pH}$ was significantly $(P<0.05)$ influenced by the addition of BP culture, HP treatment, and ripening time (Table 3). It declined until d 15 and increased afterward. Bacteriocin-producing cheeses showed 0.2 units lower $\mathrm{pH}$ values than BNP cheeses from $\mathrm{d} 7$ onward, which might be related to their higher counts of lactococci. High-pressure treatment resulted in $\mathrm{pH}$ increases of 0.1 units in both BNP and BP cheeses with respect to untreated cheeses on d 15, but those differences were reversible and were no longer found on $\mathrm{d} 25$. The instantaneous $\mathrm{pH}$ increase after HP treatment has been related to the release of colloidal calcium phosphate into the aqueous phase of the cheese (Messens et al., 1998).

Dry matter increased gradually with cheese age (Table 3). No significant differences in DM between cheeses because of BP culture addition or HP treatment of the cheese were recorded throughout the ripening period (Table 3).

\section{Release of Intracellular Enzymes}

Addition of BP culture significantly $(P<0.05)$ increased the release of aminopeptidase activity into the cheese matrix (Table 4). Thus, activity values with Leu$p$-nitroanilide as substrate in BP-NHP cheese were 2.5fold those of BNP-NHP cheese on d 1, 6.5-fold on d 7, and 6.1-fold on $\mathrm{d} 50$. The increase in aminopeptidase

Table 3. Values of $\mathrm{pH}$ and DM in Hispánico cheese manufactured without (BNP) or with (BP) a bacteriocinproducing adjunct culture, high-pressure treated (HP) on d 15 or untreated (NHP) ${ }^{1}$

\begin{tabular}{lccccr}
\hline Value & Age, d & \multicolumn{1}{c}{ BNP-NHP } & \multicolumn{1}{l}{ BNP-HP } & \multicolumn{1}{c}{ BP-NHP } & \multicolumn{1}{c}{ BP-HP } \\
\hline $\mathrm{pH}$ & 1 & $5.27 \pm 0.04$ & \multicolumn{1}{l}{-} & $5.24 \pm 0.04$ & - \\
& 7 & $5.23 \pm 0.06$ & - & $5.01 \pm 0.08$ & - \\
& 15 & $4.92 \pm 0.04^{\mathrm{c}}$ & $5.01 \pm 0.01^{\mathrm{d}}$ & $4.72 \pm 0.02^{\mathrm{a}}$ & $4.82 \pm 0.02^{\mathrm{b}}$ \\
& 25 & $5.09 \pm 0.02^{\mathrm{b}}$ & $5.08 \pm 0.02^{\mathrm{b}}$ & $4.88 \pm 0.02^{\mathrm{a}}$ & $4.86 \pm 0.02^{\mathrm{a}}$ \\
$\mathrm{DM}, \%$ & 50 & $5.05 \pm 0.04^{\mathrm{b}}$ & $5.07 \pm 0.05^{\mathrm{b}}$ & $4.88 \pm 0.08^{\mathrm{a}}$ & $4.86 \pm 0.15^{\mathrm{a}}$ \\
& 1 & $51.47 \pm 0.87$ & $51.19 \pm 0.73$ & $51.45 \pm 1.10$ & $51.74 \pm 0.99$ \\
& 7 & $52.75 \pm 0.67$ & $52.90 \pm 0.82$ & $52.48 \pm 0.74$ & $53.01 \pm 0.65$ \\
& 15 & $53.12 \pm 1.19$ & $54.39 \pm 0.20$ & $52.81 \pm 2.23$ & $53.71 \pm 0.23$ \\
& 25 & $53.95 \pm 0.49$ & $54.40 \pm 0.27$ & $53.21 \pm 0.53$ & $53.81 \pm 0.47$ \\
& 50 & $54.86 \pm 0.32$ & $55.21 \pm 0.40$ & $54.67 \pm 0.50$ & $55.06 \pm 0.60$ \\
\hline
\end{tabular}

${ }^{\mathrm{a}-\mathrm{d}}$ Means in the same row with different superscripts differ $(P<0.05)$.

${ }^{1}$ Mean $\pm \mathrm{SE}(\mathrm{n}=4)$ of duplicate determinations in 2 cheese-making experiments. 
Table 4. Aminopeptidase activity on lysine $p$-nitroanilide (Lys-p-NA) and leucine $p$-nitroanilide (Leu- $p$ NA), and proteolysis (o-phthaldialdehyde test) in Hispánico cheese manufactured without (BNP) or with (BP) a bacteriocin-producing adjunct culture, high-pressure treated (HP) on d 15 or untreated (NHP) ${ }^{1}$

\begin{tabular}{lcllrl}
\hline Activity & Age, $\mathrm{d}$ & BNP-NHP & BNP-HP & BP-NHP & BP-HP \\
\hline Lys- $p$-NA & 1 & $5.23 \pm 0.09^{\mathrm{a}}$ & - & $9.63 \pm 0.37^{\mathrm{b}}$ & - \\
& 7 & $1.32 \pm 0.10^{\mathrm{a}}$ & - & $8.45 \pm 0.39^{\mathrm{b}}$ & - \\
& 15 & $2.20 \pm 0.34^{\mathrm{a}}$ & $1.24 \pm 0.04^{\mathrm{a}}$ & $8.55 \pm 0.26^{\mathrm{c}}$ & $6.56 \pm 0.51^{\mathrm{b}}$ \\
& 25 & $2.11 \pm 0.23^{\mathrm{a}}$ & $1.51 \pm 0.05^{\mathrm{a}}$ & $6.52 \pm 0.48^{\mathrm{b}}$ & $5.30 \pm 0.37^{\mathrm{b}}$ \\
Leu- $p$-NA & 50 & $1.67 \pm 0.12^{\mathrm{a}}$ & $1.61 \pm 0.20^{\mathrm{a}}$ & $6.43 \pm 0.23^{\mathrm{c}}$ & $4.61 \pm 0.31^{\mathrm{b}}$ \\
& 1 & $5.81 \pm 0.20^{\mathrm{a}}$ & - & $14.29 \pm 0.83^{\mathrm{b}}$ & - \\
& 7 & $2.26 \pm 0.18^{\mathrm{a}}$ & - & $14.79 \pm 1.05^{\mathrm{b}}$ & - \\
& 15 & $3.96 \pm 0.89^{\mathrm{a}}$ & $2.10 \pm 0.20^{\mathrm{a}}$ & $18.61 \pm 0.89^{\mathrm{b}}$ & $15.37 \pm 1.18^{\mathrm{b}}$ \\
& 25 & $3.87 \pm 0.41^{\mathrm{a}}$ & $3.01 \pm 0.16^{\mathrm{a}}$ & $15.56 \pm 0.74^{\mathrm{b}}$ & $12.83 \pm 0.78^{\mathrm{b}}$ \\
Proteolysis & 50 & $2.54 \pm 0.30^{\mathrm{a}}$ & $2.22 \pm 0.26^{\mathrm{a}}$ & $15.44 \pm 0.56^{\mathrm{c}}$ & $13.30 \pm 0.36^{\mathrm{b}}$ \\
& 1 & $0.11 \pm 0.00^{\mathrm{a}}$ & - & $0.17 \pm 0.00^{\mathrm{b}}$ & - \\
& 7 & $0.16 \pm 0.00^{\mathrm{a}}$ & - & $0.27 \pm 0.00^{\mathrm{b}}$ & - \\
& 15 & $0.24 \pm 0.02^{\mathrm{a}}$ & $0.25 \pm 0.01^{\mathrm{a}}$ & $0.44 \pm 0.00^{\mathrm{b}}$ & $0.47 \pm 0.01^{\mathrm{c}}$ \\
& 25 & $0.31 \pm 0.01^{\mathrm{a}}$ & $0.34 \pm 0.01^{\mathrm{b}}$ & $0.66 \pm 0.02^{\mathrm{d}}$ & $0.60 \pm 0.02^{\mathrm{c}}$ \\
& 50 & $0.48 \pm 0.02^{\mathrm{a}}$ & $0.56 \pm 0.02^{\mathrm{b}}$ & $1.12 \pm 0.02^{\mathrm{d}}$ & $0.92 \pm 0.02^{\mathrm{c}}$ \\
\hline
\end{tabular}

${ }^{\mathrm{a}-\mathrm{d}}$ Means in the same row with different superscripts differ $(P<0.05)$.

${ }^{1}$ Mean \pm SE $(n=4)$ of duplicate determinations in 2 cheese-making experiments. Aminopeptidase activity is expressed as nanomoles of $p$-NA released per minute per gram of cheese, and proteolysis as the absorbance at $340 \mathrm{~nm}$.

activity agrees with previous reports (Garde et al., 1997; Morgan et al., 1997; Martínez-Cuesta et al., 2001).

On the other hand, HP treatment reduced aminopeptidase activity in both the BNP and BP cheeses (Table 4). The permeability of the lactococcal cell membrane increases with HP treatment (Malone et al., 2002), favoring the release of intracellular peptidases (Trujillo et al., 2000). Low to moderate (100 to $400 \mathrm{MPa}$ ) pressures may enhance enzyme activity, whereas higher pressures usually inactivate the enzymes (Malone et al., 2003). In the present work, aminopeptidase inactivation by the HP treatment apparently prevailed against the higher release of intracellular enzymes after the death of lactococcal cells, also because of HP treatment (Table 1). In Cheddar cheese, HP treatment inactivated starter bacteria, but did not induce autolysis (O'Reilly et al., 2002). Higher aminopeptidase activity was found in ewe milk cheese treated at $300 \mathrm{MPa}$ on $\mathrm{d} 1$ than in untreated cheese or in cheeses treated at 200, 400, or $500 \mathrm{MPa}$ (Juan et al., 2004).

\section{Proteolysis}

As determined by the OPA test, which detects released $\alpha$-amino groups, cheese proteolysis increased significantly $(P<0.05)$ with the addition of BP culture and with cheese age (Table 4). Proteolysis of the BPNHP cheese was 1.7-fold that of the BNP-NHP cheese on $\mathrm{d} 7$, and 2.3-fold that on $\mathrm{d} 50$. The enhancement of cheese proteolysis was associated with lower levels of thermophilic LAB (Table 1) and higher aminopeptidase activity (Table 4). These results confirm that early death of LAB in the presence of bacteriocins favors the release of intracellular peptidases and cheese proteolysis (Garde et al., 1997; Martínez-Cuesta et al., 2001; Ávila et al., 2005).

Table 5. Residual caseins in Hispánico cheese manufactured without (BNP) or with (BP) a bacteriocinproducing adjunct culture, high-pressure treated (HP) on d 15 or untreated (NHP) ${ }^{1}$

\begin{tabular}{lcccrr}
\hline Casein & Age, d & BNP-NHP & BNP-HP & BP-NHP & \multicolumn{1}{c}{ BP-HP } \\
\hline$\alpha_{\mathrm{s}}$-Casein & 1 & $74.6 \pm 1.1$ & \multicolumn{1}{c}{$-12.5 \pm 0.2^{\mathrm{a}}$} & $77.9 \pm 4.4$ & - \\
& 15 & $17.3 \pm 0.5^{\mathrm{b}}$ & $12.0 \pm 3.2^{\mathrm{d}}$ & $22.8 \pm 0.8^{\mathrm{c}}$ \\
& 25 & $5.2 \pm 0.5^{\mathrm{b}}$ & $3.1 \pm 0.2^{\mathrm{a}}$ & $8.6 \pm 0.3^{\mathrm{c}}$ & $8.7 \pm 0.5^{\mathrm{c}}$ \\
$\beta$ & 50 & $2.1 \pm 0.1^{\mathrm{b}}$ & $1.7 \pm 0.0^{\mathrm{a}}$ & $5.5 \pm 0.6^{\mathrm{d}}$ & $3.6 \pm 0.4^{\mathrm{c}}$ \\
& 1 & $95.6 \pm 1.1$ & - & $93.8 \pm 3.1$ & - \\
& 15 & $57.3 \pm 2.9^{\mathrm{b}}$ & $46.0 \pm 2.0^{\mathrm{a}}$ & $68.7 \pm 2.4^{\mathrm{c}}$ & $67.1 \pm 1.0^{\mathrm{c}}$ \\
& 25 & $54.0 \pm 4.2^{\mathrm{ab}}$ & $45.5 \pm 3.2^{\mathrm{a}}$ & $65.8 \pm 3.6^{\mathrm{c}}$ & $63.2 \pm 3.2^{\mathrm{bc}}$ \\
& 50 & $45.8 \pm 2.5^{\mathrm{a}}$ & $40.5 \pm 3.1^{\mathrm{a}}$ & $56.1 \pm 3.7^{\mathrm{b}}$ & $55.5 \pm 3.8^{\mathrm{b}}$ \\
\hline
\end{tabular}

${ }^{\mathrm{a}-\mathrm{d}}$ Means in the same row with different superscripts differ $(P<0.05)$.

${ }^{1}$ Mean $\pm \mathrm{SE}(\mathrm{n}=4)$ of duplicate determinations in 2 cheese-making experiments of proteolysis, expressed as percentage of the total amount of the respective casein initially present in milk. 
Table 6. Hydrophilic and hydrophobic peptides determined at $214 \mathrm{~nm}$, ratio of hydrophobic peptides to hydrophilic peptides, and total free AA in Hispánico cheese manufactured without (BNP) or with (BP) a bacteriocin-producing adjunct culture, high-pressure treated (HP) on d 15 or untreated (NHP) ${ }^{1}$

\begin{tabular}{llllrr}
\hline Proteolysis indicator & Age, d & BNP-NHP & BNP-HP & \multicolumn{1}{c}{ BP-NHP } & \multicolumn{1}{c}{ BP-HP } \\
\hline Peptides & & & & & \\
Hydrophobic & 15 & $69.5 \pm 2.8^{\mathrm{b}}$ & $54.9 \pm 3.8^{\mathrm{a}}$ & $84.5 \pm 4.7^{\mathrm{c}}$ & $105.7 \pm 2.1^{\mathrm{d}}$ \\
& 25 & $82.7 \pm 9.2^{\mathrm{b}}$ & $78.2 \pm 8.0^{\mathrm{a}}$ & $88.0 \pm 0.6^{\mathrm{c}}$ & $107.7 \pm 3.8^{\mathrm{d}}$ \\
Hydrophilic & 50 & $50.2 \pm 0.8^{\mathrm{a}}$ & $64.0 \pm 0.3^{\mathrm{b}}$ & $103.9 \pm 2.5^{\mathrm{c}}$ & $129.5 \pm 4.5^{\mathrm{d}}$ \\
& 15 & $83.2 \pm 2.8^{\mathrm{b}}$ & $60.5 \pm 8.8^{\mathrm{a}}$ & $105.5 \pm 0.3^{\mathrm{c}}$ & $123.5 \pm 4.6^{\mathrm{d}}$ \\
& 25 & $85.8 \pm 4.7^{\mathrm{a}}$ & $90.7 \pm 11.4^{\mathrm{b}}$ & $146.3 \pm 0.6^{\mathrm{c}}$ & $155.5 \pm 2.0^{\mathrm{d}}$ \\
Ratio & 50 & $70.6 \pm 1.2^{\mathrm{a}}$ & $86.5 \pm 4.2^{\mathrm{b}}$ & $197.0 \pm 1.4^{\mathrm{c}}$ & $206.3 \pm 0.5^{\mathrm{d}}$ \\
& 15 & $0.84 \pm 0.01^{\mathrm{b}}$ & $0.94 \pm 0.07^{\mathrm{d}}$ & $0.80 \pm 0.04^{\mathrm{a}}$ & $0.86 \pm 0.05^{\mathrm{c}}$ \\
& 25 & $0.95 \pm 0.06^{\mathrm{d}}$ & $0.87 \pm 0.02^{\mathrm{c}}$ & $0.60 \pm 0.00^{\mathrm{a}}$ & $0.69 \pm 0.02^{\mathrm{b}}$ \\
Free AA & 50 & $0.71 \pm 0.00^{\mathrm{c}}$ & $0.75 \pm 0.04^{\mathrm{d}}$ & $0.53 \pm 0.01^{\mathrm{a}}$ & $0.63 \pm 0.02^{\mathrm{b}}$ \\
& 15 & $1,340 \pm 154^{\mathrm{a}}$ & $1,732 \pm 63^{\mathrm{b}}$ & $2,529 \pm 415^{\mathrm{c}}$ & $2,867 \pm 173^{\mathrm{d}}$ \\
& 25 & $1,863 \pm 55^{\mathrm{a}}$ & $3,554 \pm 116^{\mathrm{b}}$ & $5,170 \pm 217^{\mathrm{d}}$ & $4,558 \pm 408^{\mathrm{c}}$ \\
& 50 & $2,694 \pm 93^{\mathrm{a}}$ & $4,730 \pm 170^{\mathrm{b}}$ & $7,314 \pm 380^{\mathrm{c}}$ & $7,210 \pm 44^{\mathrm{c}}$ \\
\hline
\end{tabular}

${ }^{\mathrm{a}-\mathrm{d}}$ Means in the same row with different superscripts differ $(P<0.05)$.

${ }^{1}$ Mean $\pm \mathrm{SE}(\mathrm{n}=4)$ of duplicate determinations in 2 cheese-making experiments, expressed as units of chromatogram area per milligram of cheese DM (peptides) and as milligrams per kilogram of cheese DM (AA).

Proteolysis was higher in BNP-HP cheese than in BNP-NHP cheese on d 25 and 50, but was lower in BP-HP cheese than in BP-NHP cheese (Table 4). High pressure may activate or inactivate enzymes (Malone et al., 2003), favor the release of intracellular enzymes after lysis of LAB cells (Trujillo et al., 2000), and induce conformational changes in the casein structure, making the protein more susceptible to the action of proteases (Kunugi, 1993). In the present work, peptidases were inactivated by HP, as shown by the comparison of their values in 15-d-old cheeses before and after HP treatment (Table 4). On the other hand, the enhancement of aminopeptidase release from starter cells by HP treatment was not evident from the data, although it could have been masked by enzyme inactivation caused by the HP treatment. Thus, conformational changes in the structure of caseins and peptides making these substrates more susceptible to the action of enzymes might explain the higher proteolysis values recorded in BNP-HP cheese than in BNP-NHP cheese on d 25 and 50 (Table 4). In BP-HP cheese, the inactivation of aminopeptidases by HP might have prevailed against the higher susceptibility of substrates to enzymes, resulting in lower proteolysis values than those of BPNHP cheese (Table 4). Treatment of Cheddar cheese at 100 to $400 \mathrm{MPa}$ for $20 \mathrm{~min}$ at $25^{\circ} \mathrm{C}$ had no apparent effect on $\mathrm{pH}$ 4.6-soluble nitrogen values (O'Reilly et al., 2002). Higher pH 4.6-soluble nitrogen values were reported for ewe milk cheese treated at $400 \mathrm{MPa}$ for 10 min at $12^{\circ} \mathrm{C}$ on $\mathrm{d} 15$ than for untreated cheese (Juan et al., 2004).

\section{Caseins}

Residual $\alpha_{\mathrm{s}}$-casein declined considerably during ripening in all cheeses (Table 5), from 75 to $78 \%$ on $d 1$ to 2 to $6 \%$ on d 50 , whereas $\beta$-casein was degraded to a lesser extent, with 94 to $96 \%$ intact casein on $d 1$ and

Table 7. Textural characteristics of Hispánico cheese manufactured without (BNP) or with (BP) a bacteriocinproducing adjunct culture, high-pressure treated (HP) on d 15 or untreated (NHP) ${ }^{1}$

\begin{tabular}{llllll}
\hline Textural characteristic & Age, d & \multicolumn{1}{l}{ BNP-NHP } & BNP-HP & BP-NHP & \multicolumn{1}{l}{ BP-HP } \\
\hline Fracturability, N & 15 & $14.88 \pm 1.53^{\mathrm{b}}$ & \multicolumn{1}{l}{$\mathrm{NF}^{\mathrm{a}}$} & $15.64 \pm 0.88^{\mathrm{b}}$ & $18.33 \pm 2.35^{\mathrm{b}}$ \\
& 25 & $19.27 \pm 5.97^{\mathrm{b}}$ & $\mathrm{NF}^{\mathrm{a}}$ & $22.60 \pm 0.97^{\mathrm{b}}$ & $28.45 \pm 1.69^{\mathrm{b}}$ \\
& 50 & $17.30 \pm 1.51^{\mathrm{ab}}$ & $13.58 \pm 4.48^{\mathrm{a}}$ & $24.20 \pm 3.00^{\mathrm{ab}}$ & $29.28 \pm 5.42^{\mathrm{b}}$ \\
Hardness, J & 15 & $0.13 \pm 0.00^{\mathrm{ab}}$ & $0.09 \pm 0.00^{\mathrm{a}}$ & $0.18 \pm 0.01^{\mathrm{c}}$ & $0.15 \pm 0.01^{\mathrm{bc}}$ \\
& 25 & $0.20 \pm 0.01^{\mathrm{ab}}$ & $0.16 \pm 0.02^{\mathrm{a}}$ & $0.29 \pm 0.01^{\mathrm{bc}}$ & $0.32 \pm 0.02^{\mathrm{c}}$ \\
Elasticity, N/mm & 50 & $0.23 \pm 0.06^{\mathrm{ab}}$ & $0.21 \pm 0.01^{\mathrm{a}}$ & $0.30 \pm 0.03^{\mathrm{ab}}$ & $0.34 \pm 0.06^{\mathrm{b}}$ \\
& 15 & $0.10 \pm 0.00^{\mathrm{b}}$ & $0.03 \pm 0.00^{\mathrm{a}}$ & $0.21 \pm 0.01^{\mathrm{c}}$ & $0.13 \pm 0.01^{\mathrm{b}}$ \\
& 25 & $0.18 \pm 0.01^{\mathrm{a}}$ & $0.11 \pm 0.02^{\mathrm{a}}$ & $0.46 \pm 0.03^{\mathrm{b}}$ & $0.45 \pm 0.05^{\mathrm{b}}$ \\
& 50 & $0.21 \pm 0.06^{\mathrm{a}}$ & $0.14 \pm 0.02^{\mathrm{a}}$ & $0.57 \pm 0.04^{\mathrm{ab}}$ & $0.72 \pm 0.15^{\mathrm{b}}$ \\
\hline
\end{tabular}

${ }^{\mathrm{a}-\mathrm{c}}$ Means in the same row with different superscripts differ $(P<0.05)$.

${ }^{1}$ Mean $\pm \mathrm{SE}(\mathrm{n}=12)$ of 6 determinations in 2 cheese-making experiments. NF $=$ no fracture after $75 \%$ compression. 


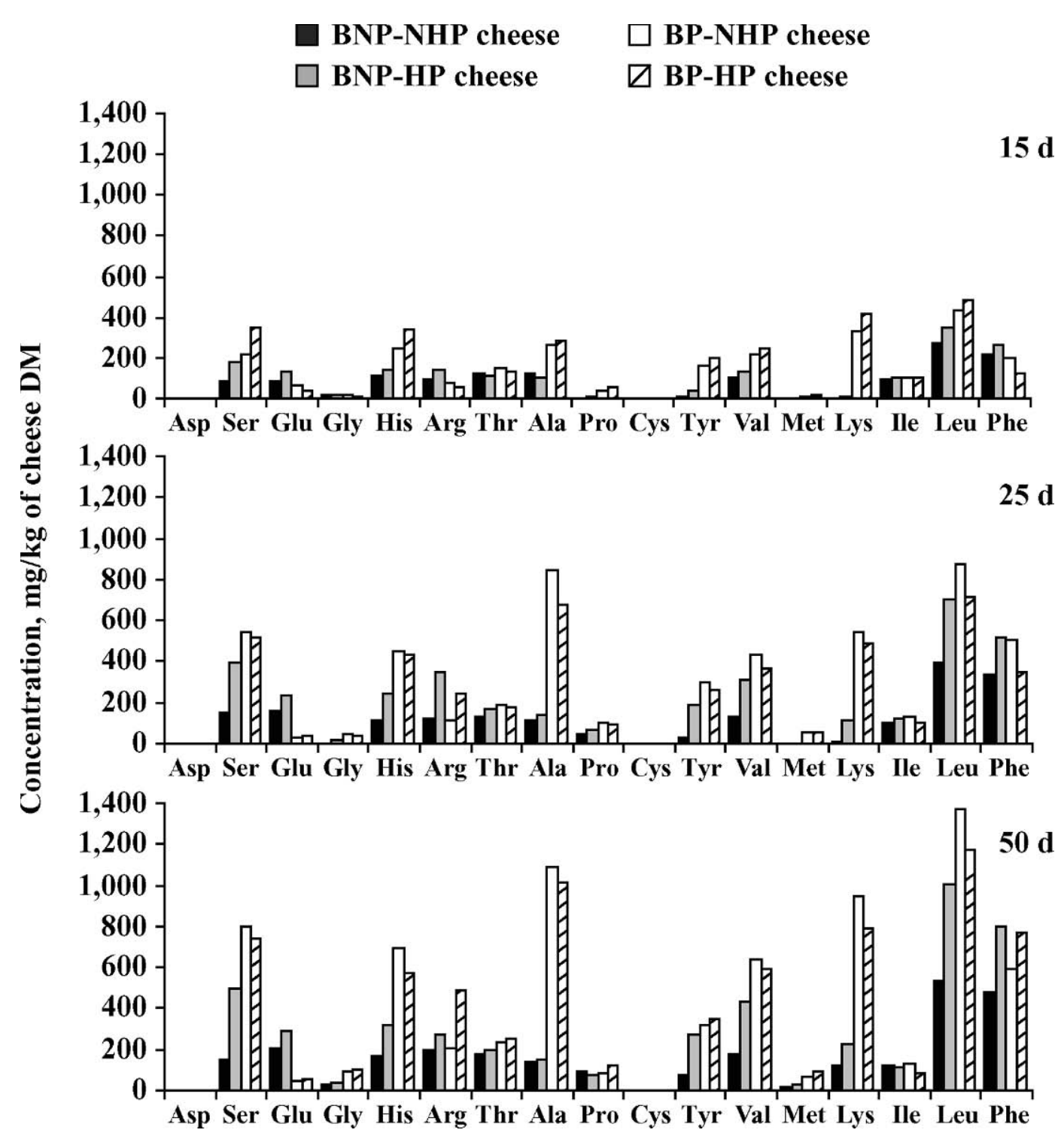

Figure 1. Concentrations of free AA after 15, 25, and $50 \mathrm{~d}$ of ripening in Hispánico cheeses made without (BNP) or with (BP) a bacteriocinproducing adjunct culture, high-pressure treated (HP) on d 15 or untreated (NHP).

41 to $56 \%$ on $\mathrm{d} 50$. Levels of $\alpha_{\mathrm{s}^{-}}$and $\beta$-casein were significantly $(P<0.05)$ lower in BNP cheeses than in $\mathrm{BP}$ cheeses from d 15 onward. The faster casein breakdown in BNP cheeses may be ascribed to its higher counts of thermophilic LAB. A similar finding was recorded for a semihard cheese variety, in which a more extensive caseinolysis took place when $S$. thermophilus was added as an adjunct culture together with the mesophilic starter (Gómez et al., 1998). Moreover, the higher $\mathrm{pH}$ values of $\mathrm{BNP}$ cheeses compared with $\mathrm{BP}$ cheeses from d 15 onward (Table 3) might have favored the activity of some proteolytic enzymes during ripening.
Caseinolysis increased with HP treatment in the present work, in particular in BNP cheeses (Table 5). However, the breakdown of $\alpha_{\mathrm{s}}$-casein was lower in Garrotxa cheese treated at $400 \mathrm{MPa}$ for $15 \mathrm{~min}$ at $14^{\circ} \mathrm{C}$ than in untreated cheese, a decrease that was explained by a reduction in residual coagulant activity (Saldo et al., 2002). In Cheddar cheese, the $\alpha_{\mathrm{s}}$-casein breakdown was increased by treatment at $100 \mathrm{MPa}$ for $70 \mathrm{~h}$ at $25^{\circ} \mathrm{C}$, but decreased when cheese was treated at 350 or $400 \mathrm{MPa}$ (O'Reilly et al., 2003). On the other hand, the $\beta$-casein breakdown was enhanced in Cheddar cheese treated at 200 to $400 \mathrm{MPa}$ for $20 \mathrm{~min}$ at $25^{\circ} \mathrm{C}$ (O'Reilly et al., 2002). The proteolytic activity of plasmin and 
Table 8. Sensory evaluation of Hispánico cheese manufactured without (BNP) or with (BP) a bacteriocinproducing adjunct culture, high-pressure treated (HP) on d 15 or untreated (NHP) ${ }^{1}$

\begin{tabular}{llllll}
\hline Characteristic & Age, d & BNP-NHP & BNP-HP & BP-NHP & BP-HP \\
\hline Taste quality & 15 & $5.19 \pm 0.42$ & $5.32 \pm 0.10$ & $5.22 \pm 0.42$ & $5.12 \pm 0.03$ \\
& 25 & $5.62 \pm 0.05$ & $5.73 \pm 0.11$ & $5.17 \pm 0.07$ & $5.31 \pm 0.09$ \\
Taste intensity & 50 & $5.33 \pm 0.31$ & $5.44 \pm 0.17$ & $5.92 \pm 0.41$ & $5.24 \pm 0.15$ \\
& 15 & $4.47 \pm 0.53^{\mathrm{ab}}$ & $4.02 \pm 0.41^{\mathrm{a}}$ & $5.50 \pm 0.24^{\mathrm{c}}$ & $5.25 \pm 0.66^{\mathrm{bc}}$ \\
& 25 & $4.97 \pm 0.45^{\mathrm{a}}$ & $5.11 \pm 0.17^{\mathrm{a}}$ & $5.78 \pm 0.30^{\mathrm{b}}$ & $5.74 \pm 0.36^{\mathrm{b}}$ \\
& 50 & $5.95 \pm 0.05$ & $5.89 \pm 0.44$ & $6.34 \pm 0.33$ & $6.47 \pm 0.38$ \\
\hline
\end{tabular}

${ }^{\mathrm{a}-\mathrm{c}}$ Means in the same row with different superscripts differ $(P<0.05)$.

${ }^{1}$ Mean $\pm \mathrm{SE}(\mathrm{n}=2)$ of scores, on a 10-point scale, from a tasting panel composed of 11 trained panelists in 2 cheese-making experiments.

chymosin did not vary in Cheddar cheese treated at $400 \mathrm{MPa}$ for $60 \mathrm{~min}$ at 8 or $20^{\circ} \mathrm{C}$ (Huppertz et al., 2004). Taking these facts into account, the increased caseinolysis recorded in the present work for HPtreated cheeses might be due to conformational changes in the structure of caseins induced by the treatment, making the proteins more susceptible to the action of plasmin, chymosin, and microbial proteinases.

\section{Peptides}

Levels of hydrophobic and hydrophilic peptides were higher in BP cheeses than in BNP cheeses throughout the ripening period, with a higher ratio of hydrophobic peptides to hydrophilic peptides in BNP cheeses than in BP cheeses (Table 6). The level of hydrophilic peptides almost doubled in BP cheeses from d 15 to d 50, with a much lower increase in hydrophobic peptides, resulting in their low peptide ratio. A decrease in peptide ratios in cheeses made with $\mathrm{BP}$ cultures has previously been reported (Ávila et al., 2005). Quantification of individual peptides present in cheese to ascertain their contribution to cheese bitterness is toilsome. For this reason the association of some chemical indexes to cheese bitterness was previously investigated, and it was concluded that the ratio of hydrophobic peptides to hydrophilic peptides is directly related to cheese bitterness (Lau et al., 1991; Gómez et al., 1997). On this basis, the lower peptide ratio found for BP cheeses might be beneficial for their flavor quality.

Levels of hydrophobic and hydrophilic peptides in 50d-old HP cheeses were higher than in the respective NHP cheeses (Table 6), in accordance with the lower levels of residual caseins in HP cheeses (Table 5). The ratio of hydrophobic peptides to hydrophilic peptides was also higher in 50-d-old HP cheeses than in the respective NHP cheeses (Table 6), most probably because of the lower aminopeptidase activity of the former cheeses. Our results agree with the higher index of hydrophobicity found for goat milk cheese treated at $400 \mathrm{MPa}$ for $15 \mathrm{~min}$ at $14^{\circ} \mathrm{C}$ compared with untreated cheese (Saldo et al., 2002).

\section{Free Amino Acids}

Total FAA were significantly $(P<0.05)$ increased by the addition of $\mathrm{BP}$ cultures to milk and by ripening time. The levels in BP-NHP cheese were 1.9-, 2.8-, and 2.7-fold the respective values in BNP-NHP cheese on d 15, 25, and 50 (Table 6). Higher levels of FAA in cheeses made with a BP culture have previously been reported (Morgan et al., 1997; Ávila et al., 2005). The higher levels of FAA in BP-NHP cheese can be explained by a more rapid breakdown of the peptides originating from casein when intracellular peptidases are released into the cheese matrix (Morgan et al., 1997)

Total FAA were higher in HP cheeses than in the respective NHP cheeses after treatment on d 15 (Table 6). From d 25 onward, BNP-HP cheese showed higher total FAA contents than BNP-NHP cheese, but total FAA contents were lower in BP-HP cheese than in BPNHP cheese (Table 6). After $50 \mathrm{~d}$, more than 2-fold increases of individual FAA were recorded for Tyr, Ser, and Val in BNP-HP cheese compared with BNP-NHP cheese (Figure 1). In Cheddar cheese treated at different pressures, levels of FAA decreased as pressures increased above $50 \mathrm{MPa}$, a result that was related to peptidase inactivation (O'Reilly et al., 2003). Similarly, FFA evolved at lower rates in 30-d-old Cheddar cheese treated at 400,500, or $800 \mathrm{MPa}$ than in control cheese (Wick et al., 2004). Garrotxa cheese treated at $400 \mathrm{MPa}$ for 5 min at $14^{\circ} \mathrm{C}$ min showed higher levels of total FAA than untreated cheese, but lower contents of Asp, Cys, and His (Saldo et al., 2002). Higher FAA contents were found in 1-d-old ewe milk cheese treated at $300 \mathrm{MPa}$ for $10 \mathrm{~min}$ at $12^{\circ} \mathrm{C}$ than in untreated cheese or in cheeses treated at 400 or $500 \mathrm{MPa}$, and these were related to a higher aminopeptidase activity (Juan et al., 2004). In the present work, aminopeptidases were inactivated by HP treatment (Table 4). Thus, conformational changes in the structure of peptides caused by HP, making substrates more susceptible to the action of peptidases, would be a possible explanation for the enhanced formation of FAA in BNP-HP cheese throughout ripening. 
On the other hand, inactivation of peptidases by HP treatment in BP-HP cheese on d 15 most probably prevailed against the higher susceptibility of substrates to enzymes, resulting in lower total FAA contents in BPHP cheese than in BP-NHP cheese from d 25 onward.

\section{Texture}

The fracturability, hardness, and elasticity of cheeses (Table 7) increased significantly $(P<0.05)$ during ripening, probably because the strengthening effect of moisture loss during ripening predominated over the weakening effect of caseinolysis. Textural characteristics, in particular hardness and elasticity, were higher in BPNHP cheese than in BNP-NHP cheese. Residual $\alpha_{\mathrm{s}}$-casein plays a crucial role in the stability of the cheese protein network (Creamer and Olson, 1982), and caseins were degraded less in BP cheese than in BNP cheese (Table 5). A relationship between lower levels of residual $\alpha_{\mathrm{s}}$-casein in Hispánico cheese and softer cheese texture has previously been recorded (Ávila et al., 2005).

High-pressure treatment softened the texture of BNP cheese immediately after treatment. Values for textural characteristics remained lower in BNP-HP cheese than in BNP-NHP cheese after d 15 (Table 7), although the differences were scarcely significant. In contrast, values for textural characteristics tended to be higher in BPHP cheese than in BP-NHP cheese after $d 15$. The opposite effect of HP treatment on the texture of BNP and BP cheeses (Table 7) might be partly explained by the firmer texture of BP cheese before HP treatment, and thus greater resistance to compression, probably because of its higher content of residual caseins (Table 5). Softening of the texture by HP treatment has been reported for Gouda cheese (Messens et al., 2000).

\section{Sensory Evaluation}

Taste quality was not significantly influenced by BP culture addition, HP treatment, or cheese age (Table 8). However, taste intensity scores increased significantly $(P<0.05)$ with BP culture addition and cheese age, most probably because of the increase in the levels of short-chain peptides and FAA.

Scores for Hispánico cheese taste descriptors were (overall mean scores for all cheeses at all ages, on a 0to 6 -point scale) $2.00,0.94,0.28,1.28$, and 1.19 , respectively, for "sour," "bitter," "sweet," "salty," and "umami." Taste descriptor scores were not significantly $(P<0.05)$ influenced by HP treatment. However, BP cheeses showed significantly $(P<0.05)$ higher "sour" $(2.77$ vs. $1.25)$ and lower "sweet" ( 0.16 vs. 0.40$)$ scores than BNP cheeses. From d 15 to d 50, overall mean scores of "bit-

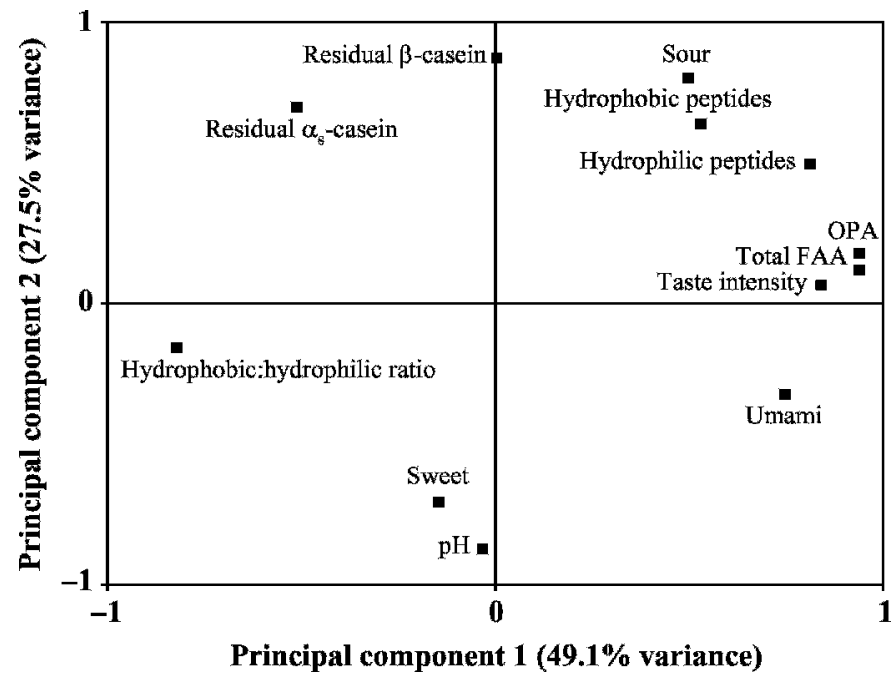

Figure 2. Principal components analysis plot showing the distribution of cheese $\mathrm{pH}$, proteolysis variables [residual caseins, hydrophobic and hydrophilic peptides and their ratio, proteolysis after the $o$ phthaldialdehyde (OPA) test, and total free AA (FAA)], and taste attributes (intensity and individual descriptors of "sour," "sweet," and "umami").

ter," "sweet," and "umami" taste descriptors increased significantly $(P<0.05)$, from 0.66 to 1.27 , from 0.26 to 0.39 , and from 1.03 to 1.42 , respectively.

A principal components analysis was carried out to correlate $\mathrm{pH}$ and proteolysis variables with taste intensity and taste descriptors (Figure 2). Principal component (PC) 1 explained $49.1 \%$ of the variance and could be defined as a "degree of ripening" factor. It correlated positively with proteolysis (OPA test), total FAA, hydrophilic peptides, taste intensity, and the taste descriptor "umami," and negatively with the ratio of hydrophobic peptides to hydrophilic peptides. Principal component 2 explained $27.5 \%$ of the variance and could be defined as a "bacteriocin" factor. It correlated positively with residual $\beta$ - and $\alpha_{\mathrm{s}}$-caseins, hydrophobic peptides, and the taste descriptor "sour," and negatively with $\mathrm{pH}$ and the taste descriptor "sweet." A third component, PC3, accounted for only $6.6 \%$ of the variance and was not correlated with cheese sensory characteristics. Plotting of cheeses at different stages of ripening in the 2-dimensional coordinate system defined by PC1 and PC2 (Figure 3 ) shows that BP cheeses always exhibited a higher degree of ripening at a certain age than did the respective BNP cheeses. One can also see that the degree of ripening increased with age within both $\mathrm{BP}$ cheeses and BNP cheeses.

\section{CONCLUSIONS}

High-pressure treatment lowered counts of mesophilic and thermophilic LAB in cheese and caused a 


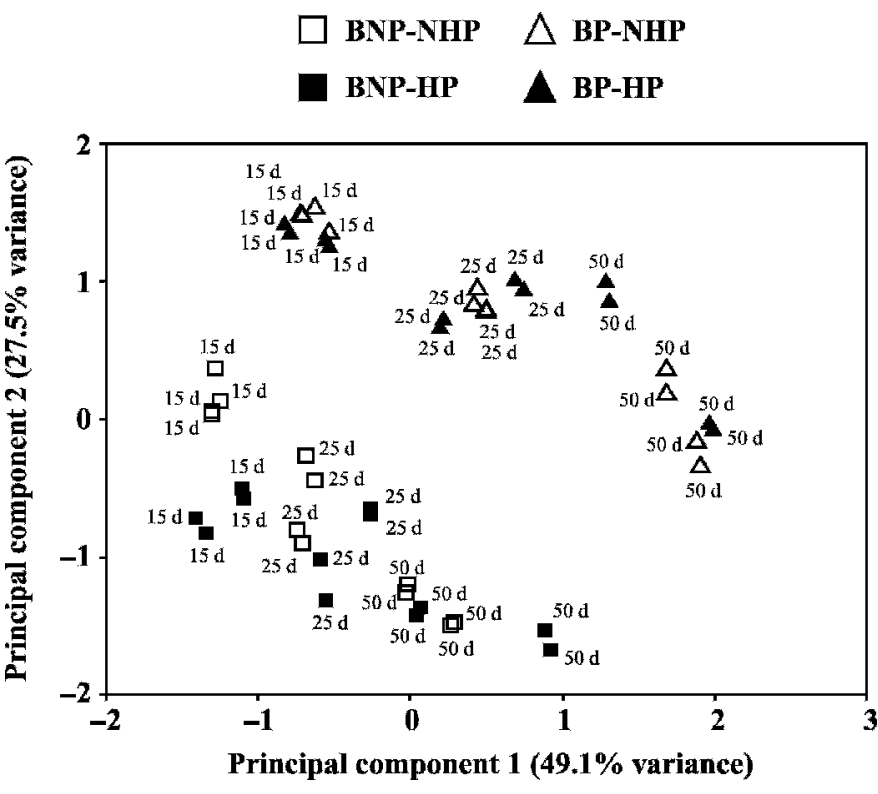

Figure 3. Distribution of 15-, 25- and 50-d-old cheeses in the plane defined by principal components 1 and 2 of the principal components analysis in Figure 2. BP = cheese made with bacteriocin producer; $\mathrm{BNP}=$ cheese made without bacteriocin producer; $\mathrm{HP}=$ high-pressure-treated cheese; NHP = cheese not treated by high pressure.

decrease in activity levels of released intracellular aminopeptidases. Primary and secondary proteolysis were accelerated in HP-treated cheeses, but HP treatment did not significantly influence taste quality or taste intensity. Cheese made from milk inoculated with the BP culture showed accelerated secondary proteolysis during ripening and a more rapid development of the characteristic cheese taste, thus receiving higher taste intensity scores. The combination of addition of $\mathrm{BP}$ culture to the milk and HP treatment of the cheese had a synergistic effect on the reduction of mesophilic LAB counts, decelerated secondary proteolysis, and did not vary cheese sensory characteristics compared with those of nonpressurized cheese. High-pressure treatment softened the texture of cheese made from milk without the $\mathrm{BP}$ culture, but had the opposite effect on cheese made from milk with BP culture added. The complex phenomena induced by the HP treatment of cheese require further research before the ripening process is mastered.

\section{ACKNOWLEDGMENTS}

This work was supported by projects AGL 2000-1426 and RTA 01-044. The authors thank NC Hyperbaric (Burgos, Spain) for HP treatment of the cheeses; INIA for a grant to Marta Ávila; and B. Rodríguez and M. de Paz for their valuable technical assistance.

\section{REFERENCES}

Ancos, B., M. P. Cano, and R. Gomez. 2000. Characteristics of stirred low-fat yoghurt as affected by high pressure. Int. Dairy J. 10:105-111

Arqués, J. L., E. Rodríguez, P. Gaya, M. Medina, B. Guamis, and M. Nuñez. 2005. Inactivation of Staphylococcus aureus in raw milk cheese by combinations of high pressure treatments and bacteriocin-producing lactic acid bacteria. J. Appl. Microbiol. 98:254-260.

Ávila, M., S. Garde, P. Gaya, M. Medina, and M. Nuñez. 2005. Influence of a bacteriocin-producing lactic culture on proteolysis and texture of Hispánico cheese. Int. Dairy J. 15:145-153.

Church, F. C., H. E. Swaisgood, D. H. Porter, and G. L. Catignani. 1983. Spectrophotometric assay using $o$-phthaldialdehyde for determination of proteolysis in milk and isolated milk proteins. J. Dairy Sci. 66:1219-1227.

Creamer, L. K., and N. F. Olson. 1982. Rheological evaluation of maturing Cheddar cheese. J. Food Sci. 47:631-636.

Fox, P. F., J. M. Wallace, S. Morgan, C. M. Lynch, E. J. Niland, and J. Tobin. 1996. Acceleration of cheese ripening. Antonie Leeuwenhoek Int. J. Gen. Microbiol. 70:271-297.

Garde, S., M. Ávila, M. Medina, and M. Nuñez. 2004. Fast induction of nisin resistance in Streptococcus thermophilus INIA 463 during growth in milk. Int. J. Food Microbiol. 96:165-172.

Garde, S., P. Gaya, M. Medina, and M. Nuñez. 1997. Acceleration of flavour formation in cheese by a bacteriocin-producing adjunct lactic culture. Biotechnol. Lett. 19:1011-1014.

Garde, S., J. Tomillo, P. Gaya, M. Medina, and M. Nuñez. 2002. Proteolysis in Hispánico cheese manufactured using a mesophilic starter, a thermophilic adjunct culture and bacteriocin-producing Lactococcus lactis subsp. lactis INIA 415 adjunct culture. J. Agric. Food Chem. 50:3479-3485.

Gaya, P., M. Medina, M. A. Rodríguez-Marín, and M. Nuñez. 1990. Accelerated ripening of ewes' milk Manchego cheese: The effect of elevated ripening temperatures. J. Dairy Sci. 73:26-32.

Gómez, M. J., S. Garde, P. Gaya, M. Medina, and M. Nuñez. 1997. Relationship between levels of hydrophobic peptides and bitterness in cheese made from pasteurized and raw milk. J. Dairy Res. 64:289-297.

Gómez, M. J., P. Gaya, M. Nuñez, and M. Medina. 1998. Streptococcus thermophilus as adjunct culture for a semi-hard cows' milk cheese. Lait 78:501-511.

Huppertz, T., P. F. Fox, and A. L. Kelly. 2004. Susceptibility of plasmin and chymosin in Cheddar cheese to inactivation by high pressure. J. Dairy Res. 71:496-499.

Juan, B., V. Ferragut, B. Guamis, M. Buffa, and A. J. Trujillo. 2004 Proteolysis of a high pressure-treated ewe's milk cheese. Milchwissenschaft 59:616-619.

Krause, I., A. Bockhardt, H. Neckermann, T. Henle, and H. Klostermeyer. 1995. Simultaneous determination of amino acids and biogenic amines by reversed-phase high-performance liquid chromatography of the dabsyl derivatives. J. Chromatogr. A. 715:67-79.

Kunugi, S. 1993. Modification of biopolymer functions by high pressure. Prog. Polym. Sci. 18:805-838.

Lau, K. Y., D. M. Barbano, and R. R. Rasmussen. 1991. Influence of pasteurization of milk on protein breakdown in Cheddar cheese during aging. J. Dairy Sci. 74:727-740.

Malone, A. S., T. H. Shellhammer, and P. D. Courtney. 2002. Effects of high pressure on the viability, morphology, lysis, and cell wall hydrolase activity of Lactococcus lactis subsp. cremoris. Appl. Environ. Microbiol. 68:4357-4363.

Malone, A. S., C. Wick, T. H. Shellhammer, and P. D. Courtney. 2003. High pressure effects on proteolytic and glycolytic enzymes involved in cheese manufacturing. J. Dairy Sci. 86:1139-1146.

Martínez-Cuesta, M. C., T. Requena, and C. Peláez. 2001. Use of a bacteriocin-producing transconjugant as starter in acceleration of cheese ripening. Int. J. Food Microbiol. 70:79-88.

Messens, W., K. Dewettinck, J. Van Camp, and A. Huyghebaert. 1998. High pressure brining of Gouda cheese and its effect on the cheese serum. Lebensm. Wiss. Technol. 31:552-558. 
Messens, W., D. van de Walle, J. Arevalo, K. Dewettinck, and A. Huyghebaert. 2000. Rheological properties of high-pressure treated Gouda cheese. Int. Dairy J. 10:359-367.

Morgan, S., R. P. Ross, and C. Hill. 1997. Increasing starter cell lysis in Cheddar cheese using a bacteriocin-producing adjunct. J. Dairy Sci. 80:1-10.

O’Reilly, C. E., A. L. Kelly, J. C. Oliveira, P. M. Murphy, M. A. E. Auty, and T. P. Beresford. 2003. Effect of varying high-pressure treatment conditions on acceleration of ripening of Cheddar cheese. Innov. Food Sci. Emerg. Technol. 4:277-284.

O'Reilly, C. E., P. M. O'Connor, P. M. Murphy, A. L. Kelly, and T. P. Beresford. 2000. The effect of exposure to pressure of $50 \mathrm{MPa}$ on Cheddar cheese ripening. Innov. Food Sci. Emerg. Technol. 1:109-117.

O'Reilly, C. E., P. M. O’Connor, P. M. Murphy, A. L. Kelly, and T. P. Beresford. 2002. Effects of high-pressure treatment on viability and autolysis of starter bacteria and proteolysis in Cheddar cheese. Int. Dairy J. 12:915-922.
Reps, A., I. Warminska-Radyko, A. Krzyzewska, and J. Tomasik. 2001. Effect of high pressures on Streptococcus salivarius subsp. thermophilus. Milchwissenschaft 56:131-133.

Rodríguez, E., J. L. Arqués, M. Nuñez, P. Gaya, and M. Medina. 2005. Combined effect of high pressure treatments and bacteriocinproducing lactic acid bacteria on the inactivation of Escherichia coli O157:H7 in raw milk cheese. Appl. Environ. Microbiol. 71:3399-3404.

Saldo, J., P. L. H. McSweeney, E. Sendra, A. L. Kelly, and B. Guamis. 2002. Proteolysis in caprine milk cheese treated by high pressure to accelerate cheese ripening. Int. Dairy J. 12:35-44.

Trujillo, A. J., M. Capellas, M. Buffa, C. Royo, R. Gervilla, X. Felipe, E. Sendra, J. Saldo, V. Ferragut, and B. Guamis. 2000. Applications of high pressure treatment for cheese production. Food Res. Int. 33:311-316.

Wick, C., U. Nienaber, O. Anggraeni, T. H. Shellhammer, and P. D. Courtney. 2004. Texture, proteolysis and viable lactic acid bacteria in commercial Cheddar cheeses treated with high pressure. J. Dairy Res. 71:107-115. 